\title{
Effect of crude glycerine in supplement on the intake, rumen fermentation, and microbial profile of Nellore steers grazing tropical grass $^{2 / 2}$
}

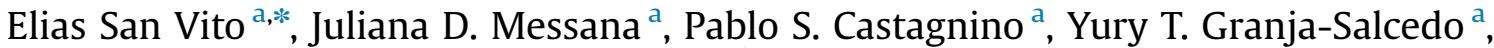 \\ Erick E. Dallantonia ${ }^{a}$, Telma T. Berchielli ${ }^{\text {a,b }}$ \\ a Department of Animal Science, College of Agrarian and Veterinarian Sciences (FCAV), Univ Estadual Paulista - UNESP, Jaboticabal, São Paulo, Brazil \\ ${ }^{\mathrm{b}}$ INCT/CA - UFV - Department of Animal Science, Viçosa, Minas Gerais, Brazil
}

\section{A R T I C L E I N F O}

\section{Article history:}

Received 16 January 2016

Received in revised form

15 August 2016

Accepted 16 August 2016

\section{Keywords:}

Bacteria

Degradation

Forage

Glycerol

Protozoa

\begin{abstract}
A B S T R A C T
The objective of this study was to evaluate the effect of crude glycerine (CG) inclusion in feed supplement $(0,70,140,210$ and $280 \mathrm{~g} / \mathrm{kg}$ DM basis of supplement) on the forage intake and digestibility, ruminal fermentation parameters, kinetics of fibre degradation, and rumen microbial profile of Nellore steers grazing on tropical grass. Ten ruminally cannulated Nellore steers [ $490 \mathrm{~kg} \pm 47$ body weight (BW)] were used in a replicated $5 \times 5$ Latin square design with 14-d periods. Steers were individually supplemented at the rate of $300 \mathrm{~g} / 100 \mathrm{~kg}$ of BW. Inclusion of CG in the supplement did not affect $(\mathrm{P}>0.05)$ dry matter intake, apparent total tract digestibility, ruminal $\mathrm{pH}(\mathrm{P}=0.784)$ or total ruminal VFA $(\mathrm{P}=0.291)$, but linearly decreased the $\mathrm{NH}_{3}-\mathrm{N}$ concentration $(\mathrm{P}=0.021)$. The inclusion of $\mathrm{CG}$ in the supplement linearly increased $(\mathrm{P}<0.001)$ the molar proportions of butyrate and valerate; linearly decreased the acetate $(P=0.007)$ concentration, thus reducing the acetate to propionate ratio $(P<0.001)$; and did not affect the molar proportions of propionate and isobutyrate. Inclusion of GC had a quadratic effect $(P=0.010)$ on the in situ potential degradable fraction of NDF and rate of fibre degradation $(\mathrm{P}=0.006)$. Addition of $\mathrm{CG}$ linearly decreased the number of protozoa of the genera Entodinium $(\mathrm{P}=0.015)$ and Isotricha $(\mathrm{P}=0.058)$ and the relative proportions of Ruminococcus albus $(\mathrm{P}=0.047)$ and Ruminococcus flavefaciens in the rumen $(P=0.036)$, but did not affect Fibrobacter succinogenes $(P=0.420)$ or the methanogens $(P=0.150)$. The inclusion of CG in the supplement up to $280 \mathrm{~g} / \mathrm{kg}$ DM altered ruminal fermentation and negatively affected in situ fibre degradation and the gram-positive cellulolytic bacterial population, but did not affect intake and apparent total tract digestibility for Nellore steers grazing tropical grass.
\end{abstract}

(c) 2016 Elsevier B.V. All rights reserved.

\section{Introduction}

Global biofuel policies have led to the shifting of large volumes of food crops to bioethanol and biodiesel production, resulting in price increases in several agricultural commodities, including corn (Popp et al., 2014). Not only is corn a stabile human food; it is an important feed grain for livestock. Its high market price is driving livestock producers to search for alternative feed sources.

Crude glycerine (CG), a by-product of biodiesel production, has become an attractive alternative to grain as an energy source in ruminant diets (Bartoň et al., 2013; Donkin et al., 2009; Mach et al., 2009). Crude glycerine is preferentially converted to propionate in

\footnotetext{
Crude glycerine for Nellore steers grazing tropical grass.

* Correspondence to: Departamento de Zootecnia, Faculdade de Ciências Agrárias e Veterinárias de Jaboticabal, São Paulo State University, Rod. Professor Paulo Donato Castellane, km 5, Rural, Jaboticabal, São Paulo CEP: 14884-900, Brazil.

E-mail address: esanvito@zootecnista.com.br (E. San Vito).
}

the rumen (Wang et al., 2009), absorbed directly by ruminal epithelium or go directly to the small intestine and then converted to glucose in the liver (Krehbiel, 2008). In addition, in vitro studies where glycerol was added to the substrate have found a linear increase in propionate to the detriment of acetic acid production (Avila-Stagno et al., 2013; Castagnino et al., 2015) and reduction in the acetate to propionate ratio (Avila et al., 2011; Bergner et al., 1995). Since propionate fermentation has been suggested as a means of reducing methane emissions, inclusion of CG in the diets of ruminants may reduce emissions, particularly when added to high-fibre diets (Rémond et al., 1993).

However, the nutritional value and ruminal fermentation parameters of inclusion of CG in forage-based diets in the literature are still insufficient. Moreover, there is a shortage of information regarding the effect of CG on microbial communities, especially those related to methane production. Only in vitro studies have produced results on the effect of glycerol inclusion on fibre degradation activity mediated by rumen microorganisms 
Table 1

Proportion of ingredients and analysed chemical composition of supplements and forage of Brachiaria brizantha 'Xaraés'.

\begin{tabular}{|c|c|c|c|c|c|c|}
\hline & \multicolumn{5}{|c|}{ Crude glycerine in the supplement, $\mathrm{g} / \mathrm{kg}$ DM } & \multirow[b]{2}{*}{ Forage $^{a}$} \\
\hline & 0 & 70 & 140 & 210 & 280 & \\
\hline \multicolumn{7}{|l|}{ Ingredient composition $^{\mathrm{b}}, \mathrm{g} / \mathrm{kg}$} \\
\hline Corn & 500.0 & 410.0 & 332.0 & 253.0 & 175.0 & - \\
\hline Crude glycerine & 0.0 & 70.0 & 140.0 & 210.0 & 280.0 & - \\
\hline Corn gluten & 0.0 & 20.0 & 28.0 & 37.0 & 45.0 & - \\
\hline Soybean meal & 420.0 & 420.0 & 420.0 & 420.0 & 420.0 & - \\
\hline Urea/ammonium sulphate & 30.0 & 30.0 & 30.0 & 30.0 & 30.0 & - \\
\hline Commercial premix ${ }^{\mathrm{C}}$ & 50.0 & 50.0 & 50.0 & 50.0 & 50.0 & - \\
\hline \multicolumn{7}{|l|}{ Chemical composition, g/kg DM } \\
\hline Dry matter & 917.0 & 915.7 & 914.0 & 912.4 & 910.8 & $890.8 \pm 28.3$ \\
\hline Organic matter & 916.2 & 913.3 & 910.4 & 907.6 & 904.8 & $918.5 \pm 4.48$ \\
\hline Crude protein & 370.5 & 370.9 & 370.6 & 370.4 & 370.1 & $180.9 \pm 23.9$ \\
\hline $\mathrm{NDF}^{\mathrm{d}}$ & 140.4 & 130.1 & 120.0 & 100.8 & 90.7 & $570.5 \pm 28.7$ \\
\hline Ether extract & 30.8 & 30.5 & 30.2 & 20.9 & 20.6 & $14.4 \pm 2.9$ \\
\hline Non-fibrous carbohydrates ${ }^{\mathrm{e}}$ & 400.7 & 410.6 & 430.0 & 440.4 & 450.9 & $138.9 \pm 24.3$ \\
\hline Crude energy, Mcal/kg of DM & 4.11 & 4.12 & 4.11 & 4.11 & 4.10 & $4.09 \pm 0.06$ \\
\hline
\end{tabular}

a Average and standard deviation of the mean of samples obtained by the technique of simulated grazing during five periods.

${ }^{\mathrm{b}}$ Chemical composition g/kg of DM=Corn - DM: 905.8, OM: 981.6, CP: 119.5, NDF: 185.3, EE: 58.8, Crude energy (CE): 4.36 Mcal; Crude glycerine - DM: 879.8, OM:

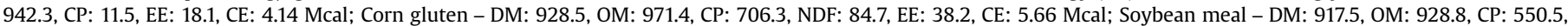
NDF: 156.1, EE: 21.6, CE: 4.59 Mcal.

c Composition=Calcium: 210 g/kg; Phosphorus: 20 g/kg; Sulphur: 37 g/kg, Sodium: 80 g/kg; Copper: 490 mg/kg; Manganese: 1.424 mg/kg; Zinc: 1.830 mg/kg; Iodine: $36 \mathrm{mg} / \mathrm{kg}$; Cobalt: $29 \mathrm{mg} / \mathrm{kg}$; Selenium: $9 \mathrm{mg} / \mathrm{kg}$; Fluorine (Max): $333 \mathrm{mg} / \mathrm{kg}$

${ }^{\mathrm{d}}$ NDF: neutral detergent fibre assayed with a heat-stable amylase and expressed exclusive of residual ash.

e Calculated as $1000-$ (crude protein + ether extract + ash + neutral detergent fibre).

(Abo El-Nor et al., 2010; Danielsson et al., 2014; Roger et al., 1992). We hypothesized that crude glycerine as an energy component could provide an alternative to partially replace corn in supplement of forage-based diets for grazing cattle, will increase propionic acid production and modify the ruminal microbial population without affecting the total apparent digestibility and dry matter intake.

Thus, the objective of the present study was to evaluate the effects of inclusion of crude glycerine $(0,70,140,210$ and $280 \mathrm{~g} / \mathrm{kg}$ $\mathrm{DM}$ of supplement) as a replacement for corn in the forage-based diet of grazing Nellore steers on intake and digestibility of DM and nutrients, rumen fermentation parameters, and the rumen microbial population.

\section{Materials and methods}

The protocol used in this experiment was in accordance with the Brazilian College of Animal Experimentation (COBEA - Colégio Brasileiro de Experimentação Animal) guidelines and was approved by the Ethics, Bioethics, and Animal Welfare Committee (CEBEA - Comissão de Ética e Bem Estar Animal) of the Faculdade de Ciências Agrárias e Veterinárias, UNESP - Univ Estadual Paulista - Jaboticabal campus (protocol number 21,119/11).

\subsection{Experimental procedures}

The trial was conducted during the rainy season at a location (Brazil, 21 ${ }^{\circ} 15^{\prime} 22^{\prime \prime}$ south, 48 ${ }^{\circ} 18^{\prime} 58^{\prime \prime}$ west and $595 \mathrm{~m}$ above sea level) owned by the Univ Estadual Paulista (UNESP, Jaboticabal, SP, Brazil) from February to May 2012. The climate is classified as tropical rainy with dry winter (Köppen international system: Aw). During the experimental period, the average monthly precipitation was $26.9 \mathrm{~mm}$, with an average maximum monthly temperature of $33.7^{\circ} \mathrm{C}$ and an average minimum monthly temperature of $13.8^{\circ} \mathrm{C}$. Ten ruminally cannulated (rubber rumen cannula $4^{\prime \prime}$, $\mathrm{KEHL}^{\circledR}$, São Carlos, BR) Nellore steers $[490.1 \pm 47.8 \mathrm{~kg}$ body weight (BW)] at $25 \pm 2$ months of age were used. Animals were distributed in a replicated $5 \times 5$ Latin square arrangement to assess the impact of different concentrations of crude glycerine (CG) in the supplement on forage intake, apparent digestibility of DM, OM, $\mathrm{CP}$ and $\mathrm{NDF}$, ruminal $\mathrm{pH}, \mathrm{NH}_{3}-\mathrm{N}$, ruminal concentration of VFA, fibre degradation, and ruminal microbiology over five 14-d periods. Each period consisted of $10 \mathrm{~d}$ of adaptation to the supplement and $4 \mathrm{~d}$ of sampling. The animals were weighed and treated against endo- and ecto-parasites by administration of ivermectin (Ivomec, Merial, Paulínea, BR) at the beginning of the experiment, then allocated into five paddocks (two animals per paddock) of 0.25 ha each. The animals and treatment were rotated between paddock. Pasture area was established in 2011, with planting of Brachiaria brizantha 'Xaraés' grass. Nitrogen was applied to each paddock as urea at a rate of $200 \mathrm{~kg} / \mathrm{ha}$, divided into two applications during the study. The paddocks were fitted with smooth wire fencing, waterers (with free access for the animals), and a pair of individual feed bunks.

Steers were individually supplemented at the rate of $300 \mathrm{~g} /$ $100 \mathrm{~kg}$ BW daily at 10:00 a.m. The experimental treatment consisted of $0,70,140,210$, and $280 \mathrm{~g} / \mathrm{kg}$ dry matter (DM) inclusion of CG in the supplement in place of corn. Crude glycerine was added to the concentrate supplement before supplementation to animals using a vertical mixer with a $500 \mathrm{~kg}$ capacity equipped with a device that allowed irrigating the CG in the other ingredients forming a homogeneous mixture. Mixing time was $10 \mathrm{~min}$.

Crude glycerine [870.98 g/kg DM; $50.72 \mathrm{~g} / \mathrm{kg}$ ash; $10.15 \mathrm{~g} / \mathrm{kg}$ crude protein (CP); $10.81 \mathrm{~g} / \mathrm{kg}$ ether extract (EE); $800.34 \mathrm{~g} / \mathrm{kg}$ glycerol; $0.3 \mathrm{~g} / \mathrm{kg}$ methanol] was purchased from a soybean-oilbased biodiesel production company (ADM, Rondonópolis, Brazil). Supplemental concentrations of corn gluten were increased with increasing CG to maintain similar concentrations of CP in the DM. Ingredients were sampled every $15 \mathrm{~d}$ to determine their chemical composition (Table 1). Individual steers' BW was recorded at the beginning of each period, without a fasting period, for adjustment of the supplementation rate.

Forage height was randomly measured weekly at 20 points using a graduated stick in each paddock (Barthram, 1985). Forage mass measurements were taken using three samples per paddock in three sampling periods during the experiment. Samples were collected by clipping all forage within a $0.25-\mathrm{m}^{2}$ frame in each 
paddock at each sampling to a $2.5-\mathrm{cm}$ stubble height with hand shears. The clipping samples were dried under forced air at $55^{\circ} \mathrm{C}$ for $72 \mathrm{~h}$. The dry weights of these clippings were multiplied by the paddock area to estimate the forage mass. The paddocks had an average forage mass of $7063.3 \pm 791 \mathrm{~kg} / \mathrm{ha}$ of DM and an average sward height of $28.3 \pm 2 \mathrm{~cm}$. A continuous grazing system was used (Allen et al., 2011), with an initial average sward height of $41.6 \pm 3.3 \mathrm{~cm}$. Forage samples were collected to represent the diet consumed by grazing steers from all pastures in each period by hand-plucking methodology designed to mimic forage selection by grazing steers (Johnson, 1978). Samples were dried to a constant weight at $55^{\circ} \mathrm{C}$ under forced air and stored before chemical analysis.

\subsection{Intake estimation}

Forage intake and apparent digestibility of total diet were estimated for each period using the marker method. Indigestible neutral detergent fibre (iNDF) and external lignin isolated marker, purified and enriched from Eucalyptus grandis (LIPE ${ }^{\circledR}-$ Simões Saliba Research products, Florestal, Brazil) were used to estimate the excretion of forage intake and fecal matter (as dry weight), respectively.

The LIPE was provided for $8 \mathrm{~d}$ by cannular infusion of a $500-\mathrm{mg}$ bolus: $5 \mathrm{~d}$ to stabilize fecal excretion of the marker and $3 \mathrm{~d}$ for sample collection (Santos et al., 2011). Fecal samples were collected on days 12,13 , and 14 of each period, directly from the rectum, at 11:00 a.m. and 4:00 p.m., 9:00 a.m. and 3:00 p.m., and 7:00 a.m. and 2:00 p.m. on the first, second, and third day of collection, respectively. Fecal samples were dried $\left(55^{\circ} \mathrm{C}\right)$, weighed, and ground in a Wiley mill (Thomas Scientific, Swedesboro, $\mathrm{NJ}$ ) to pass a 1-mm screen and composited proportionately on each of the three days of sampling, for each animal, based on fecal dry weights. Approximately $10 \mathrm{~g}$ of each sample of faeces was sent to the Federal University of Minas Gerais (Belo Horizonte, MG, Brazil) to analyse the lignin marker concentration using the infrared spectroscopy method (Saliba et al., 2013). Individual concentrate DMI was measured based on the individual supply of supplement to the animals.

The individual forage DMI was estimated using the internal marker iNDF. The samples of faeces, forage, and supplement were placed in ANKOM bags (Filter bag F57; ANKOM Technology Corporation) and incubated in the rumen of three cannulated Nellore animals for a period of $288 \mathrm{~h}$ (Valente et al., 2011). When the bags were withdrawn from the rumen, they were soaked in water for 30 min and gently washed by hand under running water until the water ran clear, then dried in an oven at $55^{\circ} \mathrm{C}$ for $72 \mathrm{~h}$. The bags were analysed for NDF concentration using an Ankom ${ }^{200}$ fibre analyzer (Ankom Inc., Fairport, NY). The result was considered the iNDF. Forage DMI was estimated from the fecal output of the internal marker corrected for the supplement contribution as follows:

Forage $\mathrm{DMI}=\frac{F E x[i M F]-D M I S x[i M S]}{[i M H]}$

where FE is the fecal excretion, DMIS is the DMI of supplement, [iMF], [iMS] and [iMH] are the concentrations of the internal marker in faeces, supplement and forage, respectively. Total DMI was obtained by addition of forage and supplement DMI.

\subsection{Chemical analysis}

For chemical analysis, samples of ingredients, supplements, and forage were dried at $55^{\circ} \mathrm{C}$ for $72 \mathrm{~h}$. Samples were then ground to pass a 1-mm screen (Thomas Scientific, Swedesboro, NJ) and analysed for dry matter (DM; 934.01), organic matter (OM; 942.05), ash (ash; 942.05), and ether extract (EE; 920.39) according to AOAC (2006). The concentration of nitrogen $(\mathrm{N})$ in each sample was determined by rapid combustion $\left(850^{\circ} \mathrm{C}\right)$, conversion of all $\mathrm{N}$-combustion products to $\mathrm{N} 2$, and subsequent measurement by a Leco $^{\circledR}$ thermoconductivity cell, model FP-528 (LECO Corporation, Michigan, USA). Crude protein was calculated as $\mathrm{N} \times$ 6.25. Neutral detergent fibre (NDF) was determined with heat-stable $\alpha$-amylase and expressed exclusive of residual ash without the addition of sodium sulphite, according to Van Soest et al. (1991) and adapted for an Ankom ${ }^{200}$ Fibre Analyzer (Ankom Technology, Fairport, NY). Non-fibrous carbohydrates (NFC; \% in the DM) were determined as $100-(\mathrm{CP}+\mathrm{NDF}+\mathrm{EE}+\mathrm{ash})$; (Mertens, 2002). For CG, chemical analysis of DM, OM and CP followed the same procedures adopted for the other ingredients. The glycerol and methanol content was provided by the biodiesel company (ADM, Rondonópilos, Brazil), and EE was calculated by difference.

\subsection{Ruminal fermentation}

Rumen $\mathrm{pH}, \mathrm{NH}_{3}-\mathrm{N}$, and VFA were measured on Day 11 of each period. Aliquots of $50 \mathrm{~mL}$ of ruminal contents were obtained at 0 , 3, 6, 12 and $18 \mathrm{~h}$ after the 10:00 a.m. supplementation. Rumen fluid was obtained from the central part of reticulorumen and was subsequently strained through two layers of cheesecloth. Ruminal $\mathrm{pH}$ was immediately measured using an electric $\mathrm{pH}$ meter (Nova Técnica, PHM, Piracicaba, SP). After pH measurement, the samples were stored at $-20^{\circ} \mathrm{C}$. To each $\mathrm{NH}_{3}-\mathrm{N}$ sample was added $1 \mathrm{~mL}$ of $9 \mathrm{M} \mathrm{H}_{2} \mathrm{SO}_{4}$. Ruminal fluid $\mathrm{NH}_{3}-\mathrm{N}$ was analysed by distillation with $2 \mathrm{M} \mathrm{KOH}$ in a micro-Kjeldahl system, according to Fenner (1965). The samples collected for analysis of VFA were centrifuged at $13,000 \times g\left(4^{\circ} \mathrm{C}\right)$ for $30 \mathrm{~min}$ and quantified by gas chromatography (GC2014, Shimatzu Corporation, Kyoto, Japan) with an HP-INNOWax capillary column $(30 \mathrm{~m} \times 0.32 \mathrm{~mm} ; 0.50 \mu \mathrm{m}$ film thickness; Agilent Technologies, Colorado, USA) at an initial temperature of $80^{\circ} \mathrm{C}$ and a final temperature of $240{ }^{\circ} \mathrm{C}$.

\subsection{Ruminal NDF degradation kinetics of forage samples}

Ruminal NDF degradation kinetics were determined in situ. Duplicate bags (F57 filter bags, 25-micron pore size, Ankom Corporation, Fairport, NY) containing a ratio of $20 \mathrm{mg}$ of $\mathrm{DM} / \mathrm{cm}^{2}$ of tissue surface of dried $\left(55^{\circ} \mathrm{C}, 72 \mathrm{~h}\right)$ and ground $(2 \mathrm{~mm})$ forage sample $(0.75 \mathrm{mg}$ of $\mathrm{DM} /$ filter bag) were placed into the rumens of each steers in each treatment at $0,3,6,9,12,24,36,48,72$, and $96 \mathrm{~h}$. Bags were soaked in warm water $\left(39^{\circ} \mathrm{C}\right)$ prior to ruminal incubation, and then insert at the specific time interval and retrieve as a group. The bags for time zero was soaked in warm water $\left(39^{\circ} \mathrm{C}\right)$, and then washing and drying normally. After removal of all bags from the rumen, the bags were washed with tap water for $30 \mathrm{~min}$. Washed bags were dried $\left(55^{\circ} \mathrm{C}, 72 \mathrm{~h}\right)$ in a forced air oven and NDF was determined according to Van Soest et al. (1991), adapted for an Ankom ${ }^{200}$ Fibre Analyzer (Ankom Technology, Fairport, NY). Percentages of disappearance of NDF at each incubation time were calculated from the proportion remaining in the bag after incubation in the rumen. Kinetics of NDF degradation were estimated according to the mathematical model of Ørskov and McDonald (1979). The model was $Y=a+b\left(1-e^{-c t}\right)$, where $\mathrm{Y}=$ degradability at time $(\mathrm{t}), \mathrm{a}=$ soluble fraction, $\mathrm{b}=$ potentially degradable fraction, $\mathrm{c}=$ fractional rate of degradation (per $\mathrm{h}$ ), and $\mathrm{t}=$ incubation time $(\mathrm{h})$.

\subsection{Rumen microbial profile}

Bacterial and protozoan samples were collected on Day 11, $3 \mathrm{~h}$ after supplementation. Rumen content aliquots, obtained by 
taking a handful of rumen contents from midpoint of the rumen, were fixed in an equal volume of $18.5 \%$ formalin, according to D'Agosto and Carneiro (1999). Ciliate protozoan species were identified and quantified in a Sedgewick-Rafter chamber, according to Dehority (1984). Each sample was homogenized and $1 \mathrm{~mL}$ of ruminal content was pipetted and transferred to vials of Lugol's solution ( $10 \mathrm{~g} \mathrm{KI} ; 100 \mathrm{~mL}$ distilled water; $5 \mathrm{~g} \mathrm{I}_{2}$ ), according to D'Agosto and Carneiro (1999). After $15 \mathrm{~min}, 9 \mathrm{~mL}$ of 30\% glycerine solution was added to the vials. To quantify the protozoa, $1 \mathrm{~mL}$ of content from each vial was pipetted to fill the Sedgewick-Rafter chamber. The ciliates were measured according to Dehority (1984).

Populations of three ruminal bacteria important for fibre degradation (Ruminococcus albus, Fibrobacter succinogenes, and $\mathrm{Ru}$ minococcus flavefaciens) and total ruminal methanogens (Archaea) were quantified by quantitative PCR. For the quantification and identification of these microorganisms, only samples from treatments with 0 and $280 \mathrm{~g} / \mathrm{kg}$ DM of CG were analysed. Fifty grams of the ruminal content were obtained by taking a handful of rumen contents from the midpoint of the rumen and placing it in a container. A second handful of rumen contents was squeezed to obtain the liquid, which was added to the same container (Henderson et al., 2013). The samples were weighed and immediately

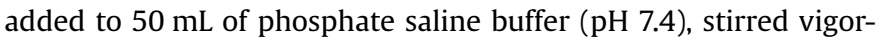
ously for $3 \mathrm{~min}$, then filtered with a mesh fabric $(100 \mu \mathrm{m})$. The filtrate was subjected to centrifugation at $16,000 \times \mathrm{g}$ for $10 \mathrm{~min}$ at $4{ }^{\circ} \mathrm{C}$. The supernatant was discarded and the remaining precipitate was resuspended in $4 \mathrm{~mL}$ of Tris-EDTA buffer (10X, pH 8.0). The resuspended content was centrifuged at $16,000 \times \mathrm{g}$ for $10 \mathrm{~min}$ at $4{ }^{\circ} \mathrm{C}$; the supernatant was then discarded, and the precipitate was immediately refrigerated $\left(-20^{\circ} \mathrm{C}\right)$. DNA extraction was conducted in $250 \mathrm{mg}$ of sample using a FastDNA ${ }^{\circledR}$ SPIN Kit for Soil (MP Biomedical, LLC). The integrity and quantity of the DNA was checked by electrophoresis on agarose gel $(0.8 \%)$. Complementary DNA was assessed by spectrophotometry (Thermo Scientific NanoDrop ${ }^{\mathrm{TM}}$ 1000) for evaluation of its quality and quantity. The primers used in this study are shown in Table 2 . Three concentrations $(400,600$, and $800 \mathrm{nM}$ ) of forward and reverse primers were tested to determine the minimum primer concentration giving the lowest threshold cycle $(\mathrm{Ct})$ and to reduce nonspecific amplification before starting the reaction. After the concentration of primers was chosen, it was validated with different concentrations of DNA (150 ng, $125 \mathrm{ng}, 100 \mathrm{ng}, 50 \mathrm{ng}$ and $25 \mathrm{ng}$ ). The value of the "slope" was determined and efficiency primers were calculated following the following equation:

\section{Table 2}

Target primers used in the relative quantification of Fibrobacter succinogenes, $R u$ minococcus flavefaciens, Ruminococcus albus, and methanogens by q-PCR.

\begin{tabular}{llc}
\hline Primer & Sequence $\left(5^{\prime}\right.$ to $\left.3^{\prime}\right)$ & Bp $^{\mathrm{a}}$ \\
\hline Total bacteria $^{\mathrm{b}}$ & F: CGGCAACGACAACCC & 130 \\
& R: CCATTGTAGCACCTGTGTAGCC & \\
Fibrobacter succinogenes $^{\mathrm{b}}$ & F: GGTATGGGATGAGCTTGC & 121 \\
& R: GCCTGCCCCTGAACTATC & \\
Ruminococcus flavefaciens $^{\text {b }}$ & F: GGACGATAATGACGGTACTT & 132 \\
Ruminococcus albus $^{\text {b }}$ & R: GCAATC(CT)GAACTGGGACAAT & \\
& F: CCCTAAAAGCAGTCTTAGTTCG & 175 \\
Methanogens $^{\mathrm{c}}$ & R: CCTCCTTGCGGTTAGAACA & \\
& F: TTCGGTGGATCDCARAGRGC & 140 \\
& R: GBARGTCGWAWCCGTAGAATC C & \\
\hline
\end{tabular}

$\mathrm{F}=$ forward; $\mathrm{R}=$ reverse.

${ }^{\text {a }}$ Amplicon size of base pairs.

${ }^{\mathrm{b}}$ Primer set from Denman and McSweeney (2006).

c Primer set from Denman et al. (2007).
Efficiency $=10(-1 /$ slope $)-1$

The amplifications were performed in triplicate and negative controls were run in the assay, omitting the total DNA. The reactions were conducted in a 7500 Real-Time PCR System (Applied Biosystems, Foster City, California 94,404, USA). ROX was used as a passive reference dye. The qPCR reaction was carried out using $120 \mathrm{ng}$ of total DNA in a reaction containing $6.25 \mu \mathrm{l}$ of $\mathrm{SYBR}^{\circledR}$ Green PCR Master Mix (Bio-Rad, Hercules, California, USA), 10 pmol of primer pair, and $\mathrm{H}_{2} \mathrm{O}$ to a final volume of $12.5 \mu \mathrm{l}$. Cycling conditions were $50{ }^{\circ} \mathrm{C}$ for $2 \mathrm{~min}$; $95^{\circ} \mathrm{C}$ for $10 \mathrm{~min}$; and 40 cycles with denaturation of $95^{\circ} \mathrm{C}$ for $15 \mathrm{~s}$, pairing $60^{\circ} \mathrm{C}$ for $1 \mathrm{~min}$, and extension $78{ }^{\circ} \mathrm{C}$ for $30 \mathrm{~s}$. After the amplification cycles, a step was added in which the temperature was increased from $60^{\circ} \mathrm{C}$ to $95^{\circ} \mathrm{C}$ to obtain the dissociation curve of the reaction products, which is used for analysing the specificity of amplification. Relative quantification was used to determine species proportions. The results were expressed as a $16 \mathrm{~S}$ rDNA ratio of general bacteria, following the equation:

Relative quantification $=2^{-(\mathrm{Ct} \text { target-Ct total bacteria) }}$

where $C_{t}$ is defined as the number of cycles required for the fluorescent signal to cross the threshold.

\subsection{Statistical analysis}

The experimental designs used for the evaluation of feed intake, digestibility, protozoa, ruminal fermentation parameters, and kinetics of fibrous particle degradation were analysed in a replicated $5 \times 5$ Latin square with 5 supplement sources, 10 animals and 5 experimental periods. Ciliated protozoan data were transformed to $\log 10$, plus a drive to meet the requirements of the SAS analysis. The statistical model included the fixed effect of treatment and random effects of Latin square, period, animal (period), and error. The interaction between treatments and Latin squares was included in the model and removed when $\mathrm{P}>0.05$. Linear and quadratic effects of CG levels were tested with orthogonal contrasts using the contrast option in the MIXED procedures of SAS. The cubic and quartic effects were not significant. Statistical evaluations of $\mathrm{pH}$, ammonia, and VFA were analysed as repeated measurements following Tempelman (2004). The errors were fitted with the Bayesian information criterion (BIC). Significance was declared when $\mathrm{P}<0.05$.

Comparison of ruminal bacteria proportion between treatments of 0 and $280 \mathrm{~g} / \mathrm{kg}$ DM of CG in the supplement were compared using a Wilcoxon test $(\mathrm{n}=10, \mathrm{P}<0.05)$.

\section{Results}

\subsection{Nutrient intake and digestibility}

Inclusion of different concentrations of CG in the supplements offered to grazing Nellore steers did not produce significant effects on the intake of total DM $(\mathrm{P}=0.490)$, forage DM $(\mathrm{P}=0.479)$, supplement $\mathrm{DM}(\mathrm{P}=0.325), \mathrm{OM}, \mathrm{CP}$ or $\mathrm{NDF}$, or the total diet apparent digestibility of DM $(\mathrm{P}=0.636), \mathrm{OM}, \mathrm{CP}$, and NDF (Table 3$)$.

\subsection{Ruminal fermentation}

The inclusion of CG in the supplement did not affect ruminal $\mathrm{pH}(\mathrm{P}=0.784)$, but linearly reduced the ruminal $\mathrm{NH}_{3}-\mathrm{N}$ concentration $(\mathrm{P}=0.021)$. Inclusion of $\mathrm{CG}$ did not affect the total ruminal VFA concentration $(\mathrm{P}=0.291)$, or the molar proportions of propionate, isobutyrate and isovalerate. However, the increase in CG levels in the supplement linearly increased the concentrations 
Table 3

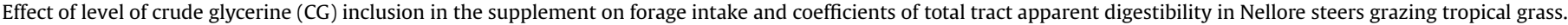

\begin{tabular}{|c|c|c|c|c|c|c|c|c|}
\hline \multirow[b]{2}{*}{ Item } & \multicolumn{5}{|c|}{ CG in the supplement, $\mathrm{g} / \mathrm{kg} \mathrm{DM}$} & \multirow[t]{2}{*}{ SEM } & \multicolumn{2}{|c|}{$P$-values ${ }^{\mathrm{a}}$} \\
\hline & 0 & 70 & 140 & 210 & 280 & & Linear & Quadratic \\
\hline \multicolumn{9}{|l|}{ Intake, $\mathrm{kg} / \mathrm{d}$} \\
\hline Total DM & 10.9 & 10.3 & 10.3 & 10.9 & 10.0 & 0.61 & 0.49 & 0.94 \\
\hline Forage DM & 9.63 & 9.00 & 8.94 & 9.65 & 8.71 & 0.63 & 0.47 & 0.93 \\
\hline Supplement DM & 1.34 & 1.33 & 1.33 & 1.33 & 1.32 & 0.06 & 0.32 & 0.98 \\
\hline $\mathrm{OM}$ & 10.0 & 9.47 & 9.44 & 10.0 & 9.24 & 0.56 & 0.49 & 0.91 \\
\hline $\mathrm{CP}$ & 2.38 & 2.16 & 2.12 & 2.38 & 2.16 & 0.18 & 0.57 & 0.54 \\
\hline $\mathrm{NDF}$ & 5.62 & 5.39 & 5.41 & 5.78 & 5.18 & 0.34 & 0.60 & 0.72 \\
\hline \multicolumn{9}{|c|}{ Digestibility, g/kg DM } \\
\hline $\mathrm{DM}$ & 579.6 & 563.3 & 567.7 & 591.3 & 548.4 & 3.25 & 0.63 & 0.69 \\
\hline $\mathrm{OM}$ & 611.6 & 591.1 & 600.9 & 616.3 & 584.8 & 3.07 & 0.68 & 0.84 \\
\hline $\mathrm{CP}$ & 729.1 & 707.8 & 704.5 & 726.7 & 681.7 & 3.07 & 0.30 & 0.79 \\
\hline NDF & 556.7 & 538.9 & 558.9 & 569.2 & 525.2 & 3.78 & 0.71 & 0.57 \\
\hline
\end{tabular}

$\mathrm{DM}$, dry matter; OM, organic matter; $\mathrm{CP}$, crude protein; NDF, neutral detergent fibre assayed with a heat-stable amylase and expressed exclusive of residual ash.

a Probability of a linear or quadratic effect of inclusion of increasing levels of CG in the supplement.

Table 4

Effect of level of crude glycerine (CG) inclusion in the supplement on $\mathrm{pH}, \mathrm{NH}_{3}-\mathrm{N}$ and volatile fatty acid concentrations in Nellore steers grazing tropical grass.

\begin{tabular}{|c|c|c|c|c|c|c|c|c|}
\hline \multirow[b]{2}{*}{ Item } & \multicolumn{5}{|c|}{ CG in the supplement, $\mathrm{g} / \mathrm{kg} \mathrm{DM}$} & \multirow[b]{2}{*}{ SEM } & \multicolumn{2}{|l|}{$P$-value ${ }^{a}$} \\
\hline & 0 & 70 & 140 & 210 & 280 & & Linear & Quadratic \\
\hline $\mathrm{pH}$ & 6.4 & 6.3 & 6.4 & 6.3 & 6.3 & 0.10 & 0.78 & 0.97 \\
\hline $\mathrm{NH}_{3}-\mathrm{N} \mathrm{mg} / \mathrm{dL}$ & 17.3 & 15.9 & 16.8 & 15.3 & 14.4 & 1.42 & 0.02 & 0.67 \\
\hline \multicolumn{9}{|l|}{$\mathrm{VFA}, \mathrm{mM}$} \\
\hline Total & 114.3 & 113.1 & 114.2 & 114.8 & 108.7 & 4.93 & 0.29 & 0.32 \\
\hline Acetate & 80.4 & 78.2 & 78.1 & 77.1 & 72.3 & 2.87 & 0.007 & 0.42 \\
\hline Propionate & 19.2 & 19.0 & 19.7 & 19.8 & 19.7 & 1.00 & 0.38 & 0.94 \\
\hline Butyrate & 11.4 & 12.5 & 12.4 & 13.8 & 13.4 & 0.71 & $<0.001$ & 0.39 \\
\hline Isobutyrate & 1.2 & 1.1 & 1.1 & 1.1 & 1.1 & 0.07 & 0.27 & 0.88 \\
\hline Valerate & 0.9 & 1.0 & 1.1 & 1.2 & 1.2 & 0.05 & $<0.001$ & 0.49 \\
\hline Isovalerate & 1.6 & 1.7 & 1.9 & 1.7 & 1.7 & 0.08 & 0.52 & 0.02 \\
\hline A: $P$ ratio ${ }^{b}$ & 4.2 & 4.0 & 4.0 & 4.0 & 3.7 & 0.10 & $<0.001$ & 0.37 \\
\hline
\end{tabular}

a Probability of a linear or quadratic effect of inclusion of increasing levels of CG in the supplement.

${ }^{\mathrm{b}}$ Acetate to propionate ratio.

of butyrate $(P<0.001)$ and valerate $(P<0.001)$. Concentration of isovalerate changed quadratically $(\mathrm{P}=0.026)$ with the higher value at $140 \mathrm{~g} / \mathrm{kg}$ of CG inclusion. The inclusion of CG in the supplement linearly decreased the acetate concentration $(P=0.007)$, consequently decreasing the acetate to propionate $(A: P)$ ratio $(\mathrm{P}<0.001$; Table 4).

\subsection{Ruminal NDF degradation kinetics of forage samples}

The inclusion of CG in the supplement quadratically altered $(P=0.010)$ the in situ potential degradable fraction of forage NDF, with the minimal point at $140 \mathrm{~g} / \mathrm{kg}$ DM inclusion of CG in the supplement. Similarly, the inclusion of CG in the supplement also quadratically affected the rate of in situ NDF degradation $(\mathrm{P}=0.006)$, with a maximum point at $70 \mathrm{~g} / \mathrm{kg}$ DM inclusion of $\mathrm{CG}$ (Table 5).

\subsection{Profile of ruminal microorganisms}

Inclusion of CG in the supplement did not change the number of protozoa of the genera Dasytricha, Eremoplastron, Diploplastron, or Polyplastron, or the number of total protozoa. However, when the concentration of CG in the supplement was increased, we observed a linear decrease in the number of protozoa of the genera Entodinium $(\mathrm{P}=0.015)$ and Isotricha $(\mathrm{P}=0.058$; Table 6$)$.

The inclusion of CG in the supplement decreased by four and six times the relative proportions of $R$. albus $(\mathrm{P}=0.047)$ and $R$.
Table 5

Effect of level of crude glycerine (CG) inclusion in the supplement on in situ ruminal fibre degradation kinetics.

\begin{tabular}{|c|c|c|c|c|c|c|c|c|}
\hline \multirow[b]{2}{*}{ Item $^{\mathrm{b}}$} & \multicolumn{5}{|c|}{ CG in the supplement, $\mathrm{g} / \mathrm{kg} \mathrm{DM}$} & \multirow[t]{2}{*}{ SEM } & \multicolumn{2}{|c|}{$P$-value ${ }^{a}$} \\
\hline & 0 & 70 & 140 & 210 & 280 & & Linear & Quadratic \\
\hline $\begin{array}{c}\mathrm{b}, \% \text { of } \\
\text { NDF }\end{array}$ & 82.61 & 72.58 & 72.14 & 72.82 & 75.18 & 4.66 & 0.02 & 0.01 \\
\hline $\begin{array}{c}c, \% \text { of } \\
\text { NDF/ } \\
h\end{array}$ & 0.0189 & 0.0258 & 0.0228 & 0.0221 & 0.0193 & 0.002 & 0.01 & 0.006 \\
\hline
\end{tabular}

The substrate incubated was composed of forage samples obtained by the technique of simulated grazing.

a Probability of a linear or quadratic effect of inclusion of increasing levels of CG in the supplement.

${ }^{b} b=$ potentially degradable fraction of NDF; $c=$ rate of degradation of B.

flavefaciens $(\mathrm{P}=0.036)$ in the rumen, respectively, but did not affect $F$. succinogenes $(P=0.420)$ or the methanogens $(P=0.150$; Table 7).

\section{Discussion}

Inclusion of CG did not affect forage intake and total tract apparent digestibility of the diet in Nellore cattle grazing tropical grass. Our findings are corroborated by a previous study showing 
Table 6

Effect of level of crude glycerine (CG) inclusion in the supplement on rumen fluid protozoan numbers in Nellore steers grazing tropical grass.

\begin{tabular}{|c|c|c|c|c|c|c|c|c|}
\hline \multirow[b]{2}{*}{ Protozoa $^{\mathrm{b}}$} & \multicolumn{5}{|c|}{ CG in the supplement, $\mathrm{g} / \mathrm{kg} \mathrm{DM}$} & \multirow[t]{2}{*}{ SEM } & \multicolumn{2}{|c|}{$P$-value ${ }^{a}$} \\
\hline & 0 & 70 & 140 & 210 & 280 & & Linear & Quadratic \\
\hline Entodinium & 6.95 & 6.92 & 6.93 & 6.89 & 6.65 & 0.07 & 0.01 & 0.06 \\
\hline Dasytricha & 5.70 & 5.80 & 5.59 & 5.55 & 5.61 & 0.15 & 0.23 & 0.81 \\
\hline Isotricha & 5.42 & 5.32 & 5.23 & 5.14 & 5.10 & 0.10 & 0.05 & 0.75 \\
\hline Eremoplastron & 2.62 & 1.79 & 2.93 & 2.14 & 2.95 & 0.62 & 0.62 & 0.58 \\
\hline Diploplastron & 2.10 & 2.51 & 2.17 & 1.70 & 1.83 & 0.55 & 0.49 & 0.75 \\
\hline Polyplastron & 2.96 & 3.30 & 3.68 & 3.76 & 4.37 & 0.68 & 0.11 & 0.90 \\
\hline Total protozoa & 25.7 & 25.6 & 26.5 & 25.1 & 26.4 & 1.07 & 0.76 & 0.89 \\
\hline
\end{tabular}

a Probability of a linear or quadratic effect of inclusion of increasing levels of CG in the supplement.

${ }^{\mathrm{b}} \log ^{10}$ of number of protozoa.

Table 7

Effect of crude glycerine (CG) inclusion in the supplement on relative proportion (\%) of cellulolytic bacteria and methanogens in Nellore steers grazing tropical grass. CG in the supplement, $\mathrm{g} / \mathrm{kg}$ DM

\begin{tabular}{lllll}
\cline { 2 - 3 } Item & 0 & 280 & SEM & $P$-value \\
\hline Ruminoccocus albus & 0.0702 & 0.0174 & 0.016 & 0.04 \\
Ruminoccocus flavefaciens & 0.0411 & 0.0073 & 0.009 & 0.03 \\
Fibrobacter succinogenes & 0.0203 & 0.0196 & 0.017 & 0.42 \\
Methanogens & 0.2487 & 0.1096 & 0.024 & 0.15 \\
\hline
\end{tabular}

a Differences were considered significant at $\mathrm{P} \leq 0.05$ using the Wilcoxon test.

that addition of CG up to $15 \%$ DM in ruminant forage-based diets did not affect the DM or fibre digestibility of warm-season grasses. A negative response was shown only in diets that surpassed $15 \%$ DM glycerine addition (Hess et al., 2008). In our experiments, inclusion of CG did not surpass $40 \mathrm{~g} / \mathrm{kg}$ DM of the diet (about $4 \%$ of DM). Generally, intake reduction occurs in diets with more than $120 \mathrm{~g} / \mathrm{kg}$ DM of CG (Mach et al., 2009; Parsons et al., 2009). However, these studies are based on the use of diets with a high level of grain, unlike the present work, which used a forage-based diet. The literature shows conflicting results on the effect of CG inclusion on feed intake related to the CG inclusion level, ratio of sodium in the CG, and interaction between GC and other dietary ingredients. Hales et al. (2013) and Pyatt et al. (2007) found a decrease in DMI in animals fed concentrations of CG of $5 \%$ and $10 \%$ of DM diet, respectively. Mach et al. (2009) and Gunn et al. (2010) reported no differences in DMI when CG up to $12 \%$ and $30 \%$ DM was included in growing diets. Both diets were based on high proportions of grains.

The $\mathrm{CP}$ levels in the supplement $(370 \mathrm{~g} / \mathrm{kg} \mathrm{DM})$ and consequently the diet intake $(2.42 \mathrm{~kg} /$ day $)$ were higher than the requirements of the animals used $(1.24 \mathrm{~kg} /$ day $)$. The high levels resulting from an underestimation of the $\mathrm{CP}$ values of forage, and could impact on ruminal fermentation and animal performance, through the loss of energy to eliminate the protein excess. However, the diets were isonitrogenous and the effect of high CP levels were similar in all treatments and probably do not affect the result of the study.

Although in this study the inclusion of CG in the supplement decreased the in situ potential degradability of forage NDF (Table 5), the apparent digestibility of the total diet was not affected. This may result from the fact that the inclusion of CG decreased the amount of NDF in the dietary supplement by $35.6 \%$ (Table 1). Reduction in fibre digestion was reported when glycerol was added to high-starch diets in vivo (Schröder and Südekum, 1999) and in vitro (Abo El-Nor et al., 2010). However, Kijora et al. (1998) found faster disappearance of glycerol after seven days of inclusion, indicating the rapid adaptation of rumen microorganisms to glycerol utilization; data corroborated by Krehbiel (2008). These data, coupled with the low amount of CG inclusion used in the current study, suggest that the intake and digestibility of foragebased diets may be not be affected by $4 \%$ CG inclusion of dietary DM.

The reduction in $\mathrm{NH}_{3}-\mathrm{N}$ concentration could be explained by the decrease in the number of protozoa of the genera Entodinium and Isotricha in the rumen (Table 6). These two genera of protozoa play an important role in the recycling of nitrogen in the rumen, aiding the digestion of proteins and excretion of $\mathrm{NH}_{3}-\mathrm{N}$ and amino acids into the rumen. The reduction in the number of protozoa may result in a decrease in ruminal $\mathrm{NH}_{3}-\mathrm{N}$. A similar result was found by Shin et al. (2012), who observed a reduction in ruminal $\mathrm{NH}_{3}-\mathrm{N}$ concentration when feeding CG to replace concentrate ingredients in corn silage- or cottonseed hull-based diets for lactating cows.

The reduction in molar proportion of acetate and A:P ratio is consistent with the reduction of the in situ potentially degradable fibre fraction and with the reduction in the relative population of gram-positive microorganisms involved in fibre degradation, such as $R$. albus and $R$. flavefaciens (Table 7). Findings of AbuGhazaleh et al. (2011), show that higher substitution levels of dietary corn with glycerol may adversely affect ruminal bacterial and negatively affect acetate production, agreeing with our results. Attention should be given to the fact that in the AbuGhazaleh et al. (2011) study was used pure glycerol ( $0.995 \mathrm{~g} / \mathrm{g}$ glycerol) and higher inclusion levels to those used in the present study. However, the supplement was consumed quickly by the animals after feeding resulting in a high rumen glycerol concentration. Thus, the administration method, not the amount of glycerol, may have affected the rumen fermentation.

The decrease in the concentration of acetate is somewhat expected because CG is commonly converted to propionate in the rumen (Rémond et al., 1993). However, in the present study acetate decreased, butyrate and valerate concentration increased, and no effect was observed for propionate. The increases in butyrate and valerate may have resulted from the increased production of lactate by fermentation of CG (Trabue et al., 2007) providing a substrate for Megasphaera elsdenii (Klieve et al., 2003), which has large involvement in producing these VFA. Shin et al. (2012) also found an increase in the proportions of propionic, butyric, and valeric acids to the detriment of acetate when feeding CG to replace concentrate ingredients in the corn silage- or cottonseed hull-based diets of lactating cows. However, our results differ from those reported by DeFrain et al. (2004), who found that animals supplemented with glycerol had greater total rumen VFA with greater rumen molar proportions of propionate to the detriment of the acetate to propionate ratio. Thus, our results do not confirm the propiogenic properties of glycerol, but support the possible suppression effect of glycerol on acetate formation in the rumen reported by Trabue et al. (2007). 
The inclusion of CG in the supplement decreased the in situ potential degradability but increased the degradation rate of the fibre. This may be because the glycerine reduced the extent of fibre degradation, due to negative effects on the adhesion of microorganisms to fibre and cellulolytic bacterial enzymatic activities (Roger et al., 1992). On the other hand, the reduction of in situ ruminal degradability of potentially digestible fibre fraction was consistent with the tendency of reduction of acetic concentration in the rumen with increased CG in the supplement. These results can be explained by the reduction of the relative proportion of gram-positive cellulolytic bacteria mediated by the inclusion of CG in the supplement (Table 7).

The profile of ruminal microorganisms is highly responsive to changes in the diet (Fernando et al., 2010). The linear reduction in the number of protozoa of the genera Entodinium and Isotricha when the concentration of CG in the supplement was increased suggests that these genera may also be sensitive to CG supplementation. The genus Entodinium is present in higher numbers in animals on forage-based diets, and its reduction can be linked to the negative effect of CG inclusion on microbial adhesion to the fibre, since these protozoa have the ability to adhere to the fibre and develop cellulolytic activity. The genus Isotricha has a greater capacity to ingest soluble material and starch granules in the rumen, so the inclusion of CG and reduction of the amount of starch in the diet may contribute to decreased numbers of these protozoa (Newbold et al., 2015). Currently, it is still unknown how glycerine feeding affects protozoan populations. However, it is known that butyrate concentrations in the ruminal fluid increase when numbers of ciliated protozoa rise (Whitelaw et al., 1972). In our study, although the butyrate concentration increased linearly, no changes were observed in the total numbers of ciliated protozoa.

Glycerine can inhibit the adhesion of microorganisms to fibre, modifying bacterial cell membrane permeability and thus affecting bacterial cellulolytic enzymatic activities. The reduction of the relative proportion of gram-positive cellulolytic bacteria $R$. albus and $R$. flavefaciens found in this study is consistent with previous observations that glycerine concentration higher than $5 \%$ of DM inhibited the growth of cellulolytic bacteria (Roger et al., 1992; Abo El Nor et al., 2010).

Interestingly, inclusion of CG in the supplement did not affect the relative proportion of $F$. succinogenes, indicating that $F$. succinogenes is less sensitive than $R$. albus and $R$. flavefaciens to the inhibitory effect of glycerine at the tested levels. We attribute this result to the fact that $F$. succinogenes is a gram-negative bacterium and its cell membranes differ from those of $R$. albus and $R$. flavefaciens. Furthermore, as a major ruminal cellulolytic bacterium in the rumen, $F$. succinogenes digests fibre faster and to a greater extent than $R$. albus and $R$. flavefaciens, and digests cellulose more actively than ruminococcal species (Miron and Ben-Ghedallia, 1992). F. succinogenes plays a key role in the rumen by degrading cellulose into metabolic products that are available to non-cellulolytic species such as Streptococcus bovis, Selenomonas ruminantium, and Treponema bryantii, which have been shown to grow on cellulose in the presence of $F$. succinogenes (Nouaille et al., 2005). This constitutes a physiological advantage when developing a niche in the rumen, particularly with a forage-based diet (Kobayashi et al., 2008).

Addition of CG did not affect the methanogenic Archaea population, which is consistent with previous reports showing that glycerine did not affect methanogenic Archaea populations (Danielsson et al., 2014; Castagnino et al., 2015). This may be because protozoa live in the rumen in a symbiotic relationship with $\mathrm{Ar}$ chaea (Ushida et al., 1997). Thus, the maintenance of numbers of total ciliated protozoa may have contributed to the lack of effects on the methanogenic proportions.
In conclusion, we find that the inclusion of CG in the supplement up to $280 \mathrm{~g} / \mathrm{kg} \mathrm{DM}$ (4\% DM diet) altered ruminal fermentation and negatively affected in situ fibre degradation, reducing the acetate to propionate ratio, negatively affected populations of gram-positive cellulolytic bacteria, but did not affect forage intake or total apparent digestibility in Nellore steers grazing tropical grass.

\section{Conflict of interest}

The authors declare that this paper has no conflict of interest.

\section{Acknowledgments}

We thank the São Paulo Research Foundation (FAPESP, Brazil), grant numbers 2011/06409-2 and 2011/00060-8, for supporting this work, and Cargill ${ }^{\circledR}$ for providing feed supplies for the experimental diets. The authors also wish to acknowledge the students of the Digestibility and Ruminant Food Evaluation Center of FCAV - UNESP for their support of this experiment.

\section{Appendix A. Supplementary material}

Supplementary data associated with this article can be found in the online version at doi:10.1016/j.livsci.2016.08.011.

\section{References}

Abo El-Nor, S., Abughazaleh, A.A., Potu, R.B., Hastings, D., Khattab, M.S.A., 2010. Effect of differing levels of glycerol on rumen fermentation and bacteria. Anim. Feed Sci. Technol. 162, 99-105.

AbuGhazaleh, A.A., Abo El-Nor, S., Ibrahim, S.A., 2011. The effect of replacing corn with glycerol on ruminal bacteria. J. Anim. Physiol. Anim. Nutr. 95, 313-319.

Allen, V.G., Batello, C., Berretta, E.J., Hodgson, J., Kothmann, M., Li, X., McIvor, J., Milne, J., Morris, C., Peeters, A., Sanderson, M., 2011. An international terminology for grazing lands and grazing animals. Grass Forage Sci. 66, 2-28.

AOAC (Association of Official Analytical Chemists), 2006. Official Methods of Analysis, 18th ed AOAC, Arlington, VA, USA.

Avila, J.S., Chaves, A.V., Hernandez-Calva, M., Beauchemin, K.A., McGinn, S.M., Wang, Y., Harstad, O.M., McAllister, T.A., 2011. Effects of replacing barley grain in feedlot diets with increasing levels of glycerol on in vitro fermentation and methane production. Anim. Feed Sci. Technol. 166-167, 265-268.

Avila-Stagno, J., Chaves, A.V., Ribeiro, G.O.J., Ungerfeld, E.M., McAllister, T.A., 2013. Inclusion of glycerol in forage diets increases methane production in a rumen simulation technique system. Brit. J. Nutr. 111, 829-835.

Barthram, G.T., 1985. Experimental Techniques: The HFRO Sward Stick. In: The hill farming research organization biennial report 1984/1985. Hill Farming Research Organization, Penicuik, UK, pp. 29-30.

Bartoň, L., Bureš, D., Homolka, P., Jančík, F., Marounek, M., Řehák, D., 2013. Effects of long-term feeding of crude glycerine on performance, carcass traits, meat quality, and blood and rumen metabolites of finishing bulls. Livest. Sci. 155, 53-59.

Bergner, H., Kijora, C., Ceresnakova, Z., Szakacs, J., 1995. In vitro studies on glycerol transformation by rumen microorganisms. Arch. Anim. Nutr. 48, 245-256.

Castagnino, P.S., Messana, J.D., Fiorentini, G., Jesus, R.B., San Vito, E., Carvalho, I.P.C., Berchielli, T.T., 2015. Glycerol combined with oils did not limit biohydrogenation of unsaturated fatty acids but reduced methane production in vitro. Anim. Feed Sci. Technol. 201, 14-24.

D'Agosto, M., Carneiro, M.E., 1999. Evaluation of lugol solution used for counting rumen ciliates. Rev. Bras. Zool. 16, 725-729.

Danielsson, R., Werner-Omazic, A., Ramin, M., Schnürer, A., Griinari, M., Dicksved, J., Bertilsson, J., 2014. Effects on enteric methane production and bacterial and archaeal communities by the addition of cashew nut shell extract or glycerolan in vitro evaluation. J. Dairy Sci. 97, 1-13.

DeFrain, J.M., Hippen, A.R., Kalscheur, K.F., Jardon, P.W., 2004. Feeding glycerol to transition dairy cows: effects on blood metabolites and lactation performance. J. Dairy Sci. 87, 4195-4206.

Dehority, B.A., 1984. Evaluation of subsampling and fixation procedures used for counting rumen protozoa. Appl. Environ. Microb. 48, 182-185.

Denman, S.E., McSweeney, C.S., 2006. Development of a real-time PCR assay for monitoring anaerobic fungal and cellulolytic bacterial populations within the rumen. FEMS Microb. Ecol. 58, 572-582. 
Denman, S.E., Tomkins, N., McSweeney, C.S., 2007. Quantitation and diversity analysis of ruminal methanogenic populations in response to the antimethanogenic compound bromochloromethane. FEMS Microb. Ecol. 62, 313-322.

Donkin, S.S., Koser, S.L., White, H.M., Doane, P.H., Cecava, M.J., 2009. Feeding value of glycerol as a replacement for corn grain in rations fed to lactating dairy cows. J. Dairy Sci. 92, 5111-5119.

Fenner, H., 1965. Methods for determining total volatile bases in rumen fluid by steam distillation. J. Dairy Sci. 48, 249-251.

Fernando, S.C., Purvis II, H.T., Najar, F.Z., Sukharnikov, L.O., Krehbiel, C.R., Nagaraja, T.G., Roe, B.A., DeSilva, U., 2010. Rumen microbial population dynamics during adaptation to a high grain diet. Appl. Environ. Microb. 76, 7482-7490.

Gunn, P.J., Schultz, A.F., Van Emon, M.L., Neary, M.K., Lemenager, R.P., Rusk, C.P., Lake, S., 2010. Effects of elevated crude glycerine concentrations on feedlot performance, carcass characteristics, and metabolite and hormone concentrations in finishing ewe and wether lambs. Prof. Anim. Sci. 26, 298-306.

Hales, K.E., Kraich, K.J., Bondurant, R.G., Meyer, B.E., Luebbe, M.K., Brown, M.S., Cole, N.A., MacDonald, J.C., 2013. Effects of glycerine on receiving performance and health status of beef steers and nutrient digestibility and rumen fermentation characteristics of growing steers. J. Anim. Sci. 91, 4277-4289.

Henderson, G., Cox, F., Kittelmann, S., Miri, V.H., Zethof, M., Noel, S.J., Waghorn, G.C., Janssen, P.H., 2013. Effect of DNA extraction methods and sampling techniques on the apparent structure of cow and sheep rumen microbial communities. PLoS One 8 (9), e74787. http://dx.doi.org/10.1371/journal.pone.0074787.

Hess, B.W., Lake, S.L., Gunter, S.A., 2008. Using glycerine as a supplement for foragefed ruminants. J. Anim. Sci. 86 (E-Suppl), 392-393.

Johnson, A.D., 1978. Sample preparation and chemical analysis of vegetation. In: Manejte, L.T. (Ed.), Measurement of Grassland vegetation and Animal production. Commonwealth Agricultural Bureaux, Aberustwysth, UK, pp. 96-102.

Kijora, C., Bergner, H., Götz, K.P., Bartelt, J., Szakács, J., Sommer, A., 1998. Research note: Investigation on the metabolism of glycerol in the rumen of bulls. Arch. Anim. Nutr. 51, 341-348.

Klieve, A.V., Hennessy, D., Ouwerkerk, D., Forster, R.J., Mackie, R.I., Attwood, G.T., 2003. Establishing populations of Megasphaera elsdenii YE 34 and Butyrivibrio fibrisolvens YE 44 in the rumen of cattle fed high grain diets. J. Appl. Microbiol. 95, 621-630.

Kobayashi, Y., Shinkai, T., Koike, S., 2008. Ecological and physiological characterization shows that Fibrobacter succinogenes is important in rumen fibre digestion - review. Folia Micro. 53 (3), 195-200.

Krehbiel, C.R., 2008. Ruminal and physiological metabolism of glycerine. J. Anim. Sci. 86 (E-Suppl), 392.

Mach, N., Bach, A., Devant, M., 2009. Effects of crude glycerine supplementation on performance and meat quality of Holstein bulls fed high-concentrate diets. J. Anim. Sci. 87, 632-638.

Mertens, D.R., 2002. Gravimetric determination of amylase-treated neutral detergent fibre in feeds with refluxing in beaker or crucibles: collaborative study. J. AOAC Int. 85, 1217-1240.

Miron, J., Ben-Ghedallia, D., 1992. The degradation and utilization of monosaccharide components by defined ruminal cellulolytic bacteria. Appl. Microbiol. Biot. 38, 432-437.

Newbold, C.J., de la Fuente, G., Belanche, A., Ramos-Morales, E., McEwan, N.R., 2015. The role of ciliate protozoa in the rumen. Front. Microbiol. 6, 1313.

Nouaille, R., Matulova, M., Delort, A.M., Forano, E., 2005. Oligosaccharide synthesis in Fibrobacter succinogenes S85 and its modulation by the substrate. FEBS J. 272, 2416-2427.

Ørskov, E.R., McDonald, I., 1979. The estimation of protein degradability in the rumen from incubation measurements weighted according to rate of passage. J. Agric. Sci. 92, 499-503.

Parsons, G.L., Shelor, M.K., Drouillard, J.S., 2009. Performance and carcass traits of finishing heifers fed crude glycerine. J. Anim. Sci. 87, 653-657.

Popp, J., Lakner, Z., Harangi-Rákos, M., Fári, M., 2014. The effect of bioEnergy expansion: food, energy, and environment. Renew. Sust. Energ. Rev. 32, 559-578.

Pyatt, A., Doane, P.H., Cecava, M.J., 2007. Effect of crude glycerine in finishing cattle diets. J. Anim. Sci. 1, 412, 85, E-Suppl..

Rémond, B., Souday, E., Jouany, J.P., 1993. In vitro and in vivo fermentation of glycerol by rumen microbes. Anim. Feed Sci. Technol. 41, 121-132.

Roger, V., Fonty, G., Andre, C., Gouet, P., 1992. Effects of glycerol on the growth, adhesion, and cellulolytic activity of rumen cellulolytic bacteria and anaerobic fungi. Curr. Microbiol. 25, 197-201.

Saliba, E.O.S., Gonc, Alves, N.C., Barbosa, G.S.S.C., Borges, A.L.C.C., Rodriguez, N.M., Moreira, G.R., Silva, F.A., 2013. Evaluation of the infrared spectroscopy method for the quantification of nanolipe marker in feces of dairy cattle. In: Oltjen, J.W. Kebreab, E., Lapierre, H. (Eds.), Energy and Protein Metabolism and Nutrition in Sustainable Animal Production. CA, USA. , pp. 247-248.

Santos, S.A., Valadares Filho, S.C., Detmann, E., Valadares, R.F.D., Ruas, J.R.M., Amaral, P.M., 2011. Different forage sources for F1 Holstein $\times$ Gir dairy cows. Livest. Sci. 142, 48-58.

Schröder, A., Südekum, K.H., 1999. Proceedings of 10th International Rapeseed Congress. Paper No. 241. Wratten, N., Salisbury, P.A. (Eds.), Glycerol as a byproduct of biodiesel production in diets for ruminants. In New Horizons for an Old Crop. The Regional Institute Ltd, Gosford, NSW.

Shin, J.H., Wang, D., Kim, S.C., Adesogan, A.T., Staples, C.R., 2012. Effects of feeding crude glycerine on performance and ruminal kinetics of lactating Holstein cows fed corn silage- or cottonseed hull-based, low-fibre diets. J. Dairy Sci. 95, 4006-4016.

Tempelman, R.J., 2004. Experimental design and statistical methods for classical and bioequivalence hypothesis testing with an application to dairy nutrition studies. J. Anim. Sci. 82 (E. suppl.), E162-E172.

Trabue, S., Scoggin, K., Tjandrakusuma, S., Rasmussen, M.A., Reilly, P.J., 2007. Ruminal fermentation of propylene glycol and glycerol. J. Agric. Food Chem. 55, 7043-7051.

Ushida, K., Mewbold, C.J., Jouany, J.P., 1997. Interspecies hydrogen transfer between the rumen ciliate Polyplastron multivesiculatum and Methanosarcina barkeri. J. Gen. Appl. Microbiol. 43, 129-131.

Valente, T.N.P., Detmann, E., Queiroz, A.C., Valadares Filho, S.C., Gomes, D.I., Figueiras, J.F., 2011. Evaluation of ruminal degradation profiles of forages using bags made from different textiles. Rev. Bras. Zootecn. 40, 2565-2573.

Van Soest, P.J., Robertson, J.B., Lewis, B.A., 1991. Methods for dietary fibre, and nonstarch polysaccharides in relation to animal nutrition. J. Dairy Sci. 74, 3583-3597.

Wang, C., Lui, Q., Huo, W.J., Yang, W.Z., Dong, K.H., Huang, Y.X., Guo, G., 2009. Effects of feeding glycerol on rumen fermentation, urinary excretion of purine derivatives and feed digestibility in steers. Livest. Sci. 121, 15-20.

Whitelaw, F.G., Eadie, J.M., Mann, S.O., Reid, R.S., 1972. Some effects of rumen ciliate protozoa in cattle given restricted amounts of a barley diet. Brit. J. Nutr. 27, 425-437. 